\title{
VISEGRAD FOUR IN BOSNIA-HERZEGOVINA. STATE-BUILDING AND EU APPROXIMATION FROM A CENTRAL EUROPEAN PERSPECTIVE ${ }^{1}$
}

\author{
CHRISTOPHER WALSCH \\ Visiting Professor, International Study Programs, Corvinus University Budapest, and New Central \\ Europe Scholar, Institute for Social and European Studies, Köszeg (Hungary); \\ E-mail: christopher.walsch@uni-corvinus.hu
}

\begin{abstract}
This article analyses the approximation of Bosnia-Herzegovina to the European Union (EU) from a Central European perspective, with a focus on the role of the Visegrad Four (V4) states in this process. The article sets out with two strategies of state-building exercised by the West in the aftermath of the Dayton Peace Treaty - a 'hands-on' and 'hands-off' (or ownership) strategy. It analyses the position of the Visegrad states towards these strategies. The text mainly explains the overall engagement of V4 in the context of EU enlargement policies. The article asks to what extent the four partners cooperate with each other and with likely regional partners Croatia, Slovenia, and Austria. The positions of the Central European states are informed by qualitative interviews with stakeholders and research literature on external governance in Bosnia-Herzegovina. It is concluded that the V4's engagement is limited due to small budget commitments and to a significant overlap of V4 positions with the positions of more active European partners.
\end{abstract}

Key words: Visegrad Four, Visegrad Group, Bosnia-Herzegovina, external governance, regimebuilding

JEL codes: E60, N40, P48

1 This research was realised in the framework of the TÁMOP 4.2.4.A/2-11-1-2012-0001 "National Excellence Programme - Elaborating and operating an inland student and researcher personal support system convergence programme" key project, which is subsidised by the European Union and Hungary and co-financed by the European Social Fund. 


\section{INTRODUCTION}

This article analyses the approximation of Bosnia-Herzegovina to the European Union (EU) from a Central European perspective. Since the Peace Treaty of Dayton in December 1995, Bosnia-Herzegovina has been under close supervision by the international community. The United States of America and major European states have a strong interest in integrating the country into the West and the European Union. This interest is shared by the smaller and newer states of the European Union that are geographically close and culturally similar to Bosnia-Herzegovina. The article specifically tests the interests and ambitions of the Visegrad Four (V4) states, Poland, the Czech Republic, Slovakia, and Hungary in Bosnia. ${ }^{2}$ The Western Balkan states and their proximity to the EU has been a constant issue for the Visegrad states over the last years. The V4 presidency programmes and reports reflect this concern (Visegrad Group 2012; 2013; 2014). V4 cooperation in EU enlargement affairs has intensified over time (Král - Bartovic 2012; Strážay 2012; Żornaczuk 2013). All four Visegrad states have a profound interest in the region. Their own transformation and EU integration experience has put the V4 in a position of seeing themselves in the roles of ideal advocates and advisers for prospective EU members who have to overcome many obstacles on their way to full membership (Walsch 2014). The research question is as follows: to what extent do the Visegrad Four states cooperate and coordinate their policies in order to encourage Europeanization in Bosnia? In order to assess the degree of cooperation, original empirical research was undertaken in 2014. The article's sources are in-depth qualitative interviews with stakeholders conducted in May and June of $2014^{3}$ and are based on the ongoing academic debate of external governance in Bosnia-Herzegovina.

The text starts with a short overview of the role of the international community in the country. ${ }^{4}$ This is followed by an analysis of two competing Western external governance strategies. The third section of the article turns to the policies of

2 When speaking about the state, the terms Bosnia and Bosnia-Herzegovina are used synonymously.

3 Despite sincere efforts no representative of Hungary was available for an interview. Neither the Hungarian Ministry of Foreign Affairs nor the embassy of Hungary in Sarajevo reacted to repeated requests.

4 The most important study is the fifty-page report "Bosnia's Future" of International Crisis Group, published in July 2014. A detailed monograph on the relationship between the EU and Bosnia-Herzegovina is Tolksdorf (2012). A commendable monograph on ethno-politics is Dzihic (2009), on economic governance Cviić and Sanfey (2010). This article will not specifically deal with governance debates. For this see the edited volume of Risse (2011) and, applied to the case of Bosnia-Herzegovina, the edited volume of Keil and Perry (2015). 
the Visegrad Four states. The fourth section deals with the policies of additional Central European states. The last section considers scenarios of competition between Western and non-Western actors in the country. Finally conclusions will be drawn from a V4 perspective.

\section{BOSNIA-HERZEGOVINA AND THE ROLE OF THE INTERNATIONAL COMMUNITY}

The political system of Bosnia-Herzegovina and the varying roles of the international community makes the study of influence of external influence in the country complicated. ${ }^{5}$ The political system of the country stems from the Dayton Peace Treaty of December 1995. This treaty could end the war and gave way to a complicated mode of power-sharing between the three dominant ethnic groups and supervised by the international community. The country is divided into two entities: the highly centralized Republika Srpska and the Federation of BosniaHerzegovina. The Federation is divided into ten cantons. In all relevant institutions on all levels each of the three ethnicities (Bosniaks, Croats, and Serbs) are represented, following a proportional set-up based on the census of $1991 .{ }^{6}$ Following the tragedies of the war of 1992 to 1995 , national minorities, formerly displaced persons and returning refugees (such persons often fall in more than one of the three categories) have particular privileges. The category "ethnicity" and the principle of ethnic proportion has led to ethnic divisions in all political processes throughout the last fifteen years, which has deepened divisions in Bosnian society (Moll 2013). The political elites of the country as well as the international community can be held responsible for this process. This type of "ethno-proportion" excludes, per definition, citizens from political office, who do not define themselves ethnically, e.g. citizens who are the offspring of mixed marriages or citizens who define themselves simply as Bosnians, not as Bosniaks (i.e. Muslim Bosnians), (Bosnian) Serbs, or (Bosnian) Croats. This discrimination led to legal claims at the European Court of Human Rights in which the plaintiffs were given their rights. In the Sejdić-Finci case of 2009, which thus became famous, the court ruled that the existing constitution of Bosnia-Herzegovina violates the human rights of their citizens. The EU now insists on the implementation of this

\footnotetext{
For an overview see Keranen (2013) and Keil (2013a and 2013b).

6 A newer census is not available. The international community put pressure on state authorities to enable legislation for a new census, which took place in 2012. This census has not yet been concluded. This is mainly for tactical reasons because politicians of all three ethnic groups fear losses (partly due to emigration) and thus a loss of influence. No Bosnian politician seems to have interest that the more recent data are made public.
} 
court judgement (i.e. the constitution of the country has to be modified accordingly), and makes all further rapprochement between the EU and the country dependent on implementation. This is why the Stabilisation and Association Agreement of the year 2008, although ratified, has not yet been fully operational. All working groups and institutional communication since occur pragmatically and bear the name "interim."

The international community, acting on the basis of UN Security Council resolutions, established the Office of the High Representative (OHR), operating originally with more than 600 staff, though today has been reduced to roughly $100 .^{7}$ The two most powerful institutions are the High Representative and the Steering Group of the Peace Implementation Council of the international community. The Steering Group consists of eleven actors (engaged EU states, large and small, the European Commission, the United States, Canada, and Russia). Its task is to maintain peace and ensure a functioning Bosnia. In order to carry out this responsibility, the OHR exercises executive powers (the so-called "Bonn Powers"). The OHR made extensive use of its executive powers in the first ten years of its existence from 1996 to 2005. This practice is often referred to as the "hands-on approach." Over time, a reconsideration of paradigm among international community actors occurred. Thought emerged that transformation cannot be inflicted onto Bosnian society from outside. Hence, since circa 2006, the gentler ownership principle (or "hands-off" approach) has gained prominence, arguing that Bosnian society and its elites should want change themselves and thus steer the course of change autonomously. Progress under this new principle, however, has been minimal. This is why the international community today is doubtful and partly very critical of the ownership principle translating into decreasing budgets provided by the International Monetary Fund and channelled through the OHR.

The EU and diplomats from member states are important actors as they are heavily represented in the OHR. Furthermore, in order to better separate OHR and EU agendas, the position of EU Special Envoy was created. ${ }^{8}$ This position is held by the Head of the delegation of the European Commission. The special envoy's office coordinates the agendas of the EU and the member states. As it acts mainly in policy-related issues and implementation, it is less politicised than the OHR. The contested governance issues remain the responsibility of the OHR,

7 The subsequent reduction of personnel is a consequence of the ambition of the international community to close the OHR in the likely future. This has not yet been the case, but the international community and Bosnians agreed on the criteria that have to be fulfilled in order to close down the OHR (formulated in five aims and two conditions, the so-called " $5+2$ agenda").

8 The most important reason to separate the two was greater ease to find a consensus, which has now to be found among the group of EU states only (and could neglect American and Russian positions). This was a logical step, as the budget comes from the EU states. 
i.e. the Steering Group of the Peace Implementation Council. Not only have the continued disagreements among representatives of the three ethnicities complicated OHR agendas, but so have increasing disagreements within the Steering Group. Two conflicts can be observed: that of Western representatives versus Russia, and disagreement amongst Western representatives. ${ }^{9}$

\section{THE WEST AS AN ACTOR IN BOSNIA-HERZEGOVINA: TORN BETWEEN TWO STRATEGIES}

Among the Western powers, the United States and the United Kingdom advocate a more active and interventionist role for the West. Those within the Bosniak community who define themselves as multi-ethnic support this strategy. The United States had played a proactive role in the first fifteen years since the Dayton Peace Agreement until about 2009, when USA interference waned and external governance agendas were left to the European Union. Since circa 2014, the USA has been reconsidering its strategy and may again advocate a more interventionist, "hands-on" strategy. This would translate to clear Western positions with a strong OHR, supported by a higher number of EUFOR troops, as well as the enforcement of sanctions against Bosnian politicians who violate, or do not eagerly enforce, OHR and EU decisions. Along this line of thought, it is the role of the West to oblige Bosnian politicians to consider a new peace treaty. This treaty has been dubbed "Dayton II" and aims to better govern the coexistence of the different groups of Bosnian society. Analyst Soeren Keil cites the EU's poor performance in the preceding years as the European Commission merely acted as a nonpolitical executive in charge of minor technical rules and regulations. This role, argues Keil, gave a boost to the centrifugal and secessionist forces in Bosnia:

Bosnia is a country in which a violent conflict has been frozen in the institutional architecture of the post-Dayton system. There is absolutely no willingness to compromise and agree even on basic decisions such as country-wide standards for health and safety in agriculture. The EU has long ignored this reality in Bosnia. Instead, representatives of the Union pretended that EU enlargement is a technical issue, and that all elites have to agree upon is how to adopt the technical and procedural standards of Europe. They ignore the centrifugal, secessionist forces that work against the very existence of a unified state (Keil 2013c: 4-5).

9 Since the rise of tensions between the West and Russia because of the Ukraine crisis, more OHR communiqués are published with the addendum „without Russia.“ This is to be seen in the context of Republika Srpska whose separation efforts are implicitly supported by Russia (Russia hoping for gaining more legitimacy for the 2014 annexation of Crimea). Also in 2014 it happened for the first time that Russia did not approve the annual report of the High Representative in the UN Security Council. Russia abstained, but did not veto the report. 
Thus, Soeren Keil recommends a much more active, if not forceful role for the $\mathrm{EU}$, a role that involves strict use of the all-too-well-known financial carrots and sticks policies:

\begin{abstract}
What the country needs is not less EU conditionality [...] but instead for the EU to clearly define guidelines for the required reforms and how it will support any reform efforts. But this also means that the unwillingness to reform must be penalised and that Bosnian elites should be punished for non-compliance. This might eventually result in changing electoral patterns, once people feel that elites are not taking their main demands and wishes into account. In this regard, it is important that the EU makes robust use of its financial incentives and carries through with such threats as holding back important funding until reforms have been agreed and implemented. This will change the incentives for reforms and for political compromises among leading political elites (Keil 2013c: 5).
\end{abstract}

Dissimilarly, most other EU states share the conviction that only the „ownership” strategy can harvest long-term and profound results. The Croatian and Serbian communities sympathise with this approach. Active agents within the EU that support this strategy, including the Steering Group members Germany, France, Italy, Spain, the Netherlands, and Sweden. ${ }^{10}$ Austria and Slovenia, given their geographic proximity, as well as immediate neighbour Croatia, lean towards the ownership strategy as well. This approach argues for a more efficient application of the ownership strategy. The central consideration here is that the European Union is willing to show some flexibility regarding the application and enforcement of the ruling of the European Court for Human Rights (the Sejdić-Finci case). The EU would rather not waste time because of the deadlock that the pending case brings to the EU rapprochement process, preferring to engage in so-called "High Level" (or often dubbed "parallel") negotiations on EU rapprochement. The EU would do so if and only if Bosnian elites are willing to initiate constitutional reforms in the mid and long term. A widely read analysis of the European Stability Initiative of 2013 even comes to the conclusion that insisting on the strict conditionality of the implementation of the Sejdić-Finci Judgement on behalf of the EU was a mistake: "It should not be a precondition. Making it one was a mistake" (European Stability Initiative 2013).

\title{
4. THE ROLE OF THE VISEGRAD STATES IN BOSNIA-HERZEGOVINA
}

The article will now investigate the positions of the Visegrad Four states towards Bosnia-Herzegovina. The analysis in this paragraph draws on research literature, which exclusively deals with the case of Bosnia-Herzegovina, and in

10 Great Britain is the EU Steering Group member that has rather sympathised with the hands-on positions as advocated by the United States. 
the subsequent paragraphs on the empirical research of the author conducted in mid-2014. ${ }^{11}$ Hungarian and Czech diplomats come to the conclusion that their countries' expertise concerning transformation may be helpful but their voices are not heard in the concert of external actors who compete for influence (Tolksdorf 2012: 126). ${ }^{12}$ However, V4 are not alone in their powerlessness; it is shared with all who are not represented in the Steering Group of the Peace Implementation Council. In addition, coordination among V4 and their common lobbying does not go so far as to claim a seat in the Steering Group. Some smaller states follow more proactive policies and have a seat. For example, The Netherlands, who do everything in support of Bosnia-Herzegovina to correct their role before and during the Srebrenica disaster of 1995; or Sweden, a nation in close co-ordination with the other Scandinavian countries to advocate a sincere and sustainable Human Rights agenda. Finally Spain, a bigger, but not huge, power in the region, provided EUFOR troops in great numbers and is interested in the maintenance and functioning of the state of Bosnia-Herzegovina, mainly due to the independence movements in the Catalonia region of Spain (Tolksdorf 2012: 124-128). The seemingly timid policies of the V4 states can be easily explained: V4 are in line with the policies of the more important EU actors as they identify with the positions of the EU states that are Steering Group members. Engaging separately may lead to much higher costs and contributions, which may not be worth it if the V4 can align themselves with the more active EU partners.

All three interview partners (the representatives of Slovakia, the Czech Republic, and Poland) confirm that the "sharing of institutional and procedural know-how" (Strážay 2012: 57-58) is very much applied in practice..$^{13}$ The V4 facilitate collaboration among experts from their own countries and from BosniaHerzegovina. Experts from the Visegrad countries bring their knowledge of how to best plan, budget, administer, and realize EU-funded programmes. From the Bosnian perspective, V4 is perceived as an "honest broker" with limited self-interest especially as compared to neighbouring Croatia. Thematically, the

11 A list of the interviewed persons can be found at the end of this article. All interviews were standardized qualitative interviews (length half an hour to one hour). The interviews focused on the specific country's initiatives in Bosnia-Herzegovina (be it governmental or non-governmental), on coordination with V4 partners, on coordination in the V4-Plus format, and on coordination and cooperation with EU Steering Group members and other EU partners.

12 This was implicitly also the opinion of the interviewees of the smaller Visegrad states (interviews 5 and 6). The notion that V4 see themselves in the category of second class member states was present in the interviews of Tolksdorf in the year 2008 and 2009, but not in the 2014 interviews that were conducted for this research.

13 All statements in this paragraph are based on the 2014 interviews. 
Czech Republic's programmes focus on two areas: human rights and a variety of technical issues linked to the fulfilment of criteria of the acquis communautaire, e.g. standards in agriculture, environmental requirements and health. Slovakia's nature of engagement is similar to that of the Czech Republic. This translates to co-operation projects in the areas of agriculture, waste management and energy production and efficiency. The exchange of experts in these areas is mutual, as Bosnian professionals frequently visit Slovakia. These personal and direct contacts are useful as they help minimize false perceptions regarding EU membership, argues the Slovak representative. All interlocutors came to the conclusion that it is this direct, project-related cooperation "on the ground" that best demonstrates the Bosnian partners the positive experience of EU approximation. Visegrad is certainly a role model, argues the representative of Poland, adding that economic transformation was a painful process in Poland during the times of transformation. Although many citizens lost small privileges, Polish society as a whole profited from the successful transformation to an efficiently run economy, which is today competition-based and developing into a knowledge-based economy. This process could serve as an example for Bosnia-Herzegovina.

All V4 interview partners confirmed that single projects of individual V4 states are not coordinated among V4 states. Despite this, the V4 do coordinate themselves in some way. V4 meet regularly and inform each other about their activities. This also happens in the V4-Plus format and in extended fora, where external actors are involved at all levels (ambassadors, embassy staff, and experts). ${ }^{14}$ As for information policy, V4 engages in "joint briefings." Interlocutors came to the conclusion that four individual briefings may be considered irrelevant but a joint public relations engagement allows their voices to be better heard. The Four also regularly partake in two initiatives that should help "V4 identity building." They celebrate together their national holidays on one occasion, dubbed as "Visegrad National Day" in late October or early November, a time when all four states celebrate their national holidays. They also host a common film week ("V4 film week") or common exhibitions that bring together and display productions and art originating from the four countries.

14 V4-Plus is a format in which V4 encourage partners from the Central European region to participate in common initiatives. These partners vary, depending on the policy area. V4-Plus partners are usually the three Baltic states and/or Romania and Bulgaria and/or Austria and/or Slovenia, and Croatia. 


\section{REGIONAL PARTNERS OF THE VISEGRAD STATES AND THE ROLE OF CROATIA}

The Visegrad states often wish to underline that they intend to reach out to more states of the Central European region in their activities. V4 moved to include the new member state of Croatia in their initiatives towards EU enlargement, offering the "Joint Declaration of the Foreign Ministers of the Visegrad Countries and Croatia on the Occasion of the Croatian Accession to the EU" (Visegrad Group 2013; Töglhofer 2013) on the eve of the Croatian accession. Croatia and Slovenia, however, conduct a more active policy towards Bosnia-Herzegovina. V4 are classic "decision-takers" whereas Croatia and Slovenia partly seek roles as "decision-shapers" or even "agenda-setters." Also, Austria is a regional partner with an interest in EU enlargement, persisting that Bosnia remains prominent on the EU agenda (interview 1). Austria hosted the second annual summit of the so-called Berlin Process which started in mid-2014. With this initiative Germany and like-minded partners (e.g. Austria, but also V4) wish to demonstrate that the prospective Balkan enlargements are to remain on the EU agenda despite a widespread enlargement fatigue. As to the role of the Visegrad states and their outreach to like-minded partners, the academic literature and interviews with V4 actors indicate that the V4 has done little or nothing to better include these countries in their V4-Plus format concerning Bosnia-Herzegovina. This can be considered a missed opportunity as initiatives of Croatia, Slovenia and Austria often bear the same spirit as those of V4.

Slovenia urged in February 2014 a less paternalistic and more efficient handling of Bosnia on behalf of the EU. Croatia went as far as to propose allowing Bosnia the status of "special" candidate (Euinside 2014). The Croatian proposal suggests that Bosnia should be allowed to fulfil EU conditions in the process of accession negotiations. This should happen step-by-step, bounded by strict conditionality. The Croatian proposal, however, diverges from the current rules and regulations, requiring certain conditions to be fulfilled before the start of negotiations. The proposal argues that strict conditionality during negotiations would encourage the Bosnian elite to implement all the necessary reforms the EU urges, particularly the constitutional reforms that would increase the functionality of the state. Croatia also expects much stronger participation on behalf of civil society. The Croatian proposal cites the EU accession strategies of the cases of Croatia, Montenegro, and Serbia. In each of the cases, the EU was or has been willing to accommodate specific requirements of each candidate state. The proposal also makes a reference to Serbia as the EU granted Serbia candidate status despite disagreements concerning Kosovo. Serbia underwent the screening process and 
started accession negotiations in 2014. It is argued that this flexibility on behalf of the EU is responsible for bringing Serbia on a pro-European course.

The Croatian initiative did not have an explicit impact on the protocol of the EU Foreign Ministers Council, where the proposal was discussed. Still, a "Compact for Growth" was decided upon and Croatia commented that Bosnia remains prominent on the EU agenda (Council of the European Union 2014). The Croatian proposal did, importantly, initiate a reflection process on how to move forward. ${ }^{15}$ The crucial starting point remains constitutional reform, which would transform Bosnia-Herzegovina into a functioning state. The EU Council of Ministers must now realize that the EU's approach towards enlargement may differ from one candidate country to another (a "tailor-made" approach, as it is called in the Croatian proposal). This could have an effect on other candidate states. In the Macedonian case, both sides find themselves in a similar "frozen", limbo situation, which cannot be overcome using existing strategy. In the Bosnian case, one can observe a stronger reflection, a critique of the "hands-off" approach strategy, and a search for alternatives. Even mainstream academia that is operating closely with major Western stakeholders confirms that Croatia revealed a weak point in the Western strategy. International Crisis Group's (ICG) latest in-depth study, titled "Bosnia's Future," published in July 2014, includes many recommendations that are very similar to the suggestions of the Croatian proposal of Spring 2014. The ICG study urges the closure of the OHR and the start of EU accession negotiations. Concerning constitutional reform, the ICG suggests that the EU should draw on two or three European federal models to be discussed with Bosnian stakeholders. One of them should eventually be implemented in close coordination with these stakeholders. Similar to Croatia, this study urges much stronger involvement from civil society.

In November 2014, a joint British-German initiative was launched that partly draws on the insights of the ongoing debate (Bassuener et al. 2014). It was also warmly greeted by the Croatian foreign minister as Croatia does not view it as an initiative that competes with the Croatian proposal. The initiative is a pragmatic proposal that seeks to find a way out of the current impasse. The initiative urges Bosnian politicians to commit themselves decisively to a package of (yet undefined) reforms in order to bring the long-delayed Stabilisation and Association Agreement (SAA) into force. When the SAA is made operational, Bosnia could profit from much needed financial mechanisms. The British-German initiative, also backed by the EU's new foreign policy commissioner Federica Mogherini,

15 According to the foreign minister of Croatia, Vesna Pusić, also the UK, Italy, Austria, and Hungary tabled written proposals on the issue how the EU shall move on with its Bosnia policies. See Euinside (2014.). 
indicates that unresolved economic issues are what now stand in the foreground. The immediate economic concerns of Bosnian citizens hold priority over the discrimination issue exemplified by the Sejdić-Finci ruling. The initiative does, however, state the importance of addressing the issue, but in due course. As to disagreements within the EU and the West; the joint initiative of these two powerful actors can be seen as a compromise between different viewpoints or at least a formation of a lowest common denominator. The above-mentioned Berlin Process incorporates the outcomes and progress made through the BritishGerman initiative.

\section{BOSNIA, THE WEST AND ADDITIONAL EXTERNAL ACTORS: A COMPETITION SCENARIO}

All involved in the discussion agree that Bosnia-Herzegovina has been all too long in a limbo situation. Externally launched reform initiatives have always proved unsuccessful because Bosnian politicians have not agreed with each other. The election results of October 2014 have not changed much concerning the attitudes or dominance of the actors as the ethnocentric parties won the confidence of Bosnian voters, thus perpetuating the ethnic divide among politicians. The West may react to neglected reform efforts with sanctions in the form of budget cuts. The West, however, must realize that each of the leaders of the three ethnicities may manipulate external sympathy to receive funding for their specific party. Bosniaks will naturally rely on Turkey and wealthy Arab states. Bosnian Serbs will continuously be able to count on Russian (Putin's) support, as frequent meetings of Republika Srpska president Milorad Dodik and the Russian president suggest. In this respect, some warn that Putin may be able to enter the "soft underbelly" of Europe, via Bosnia, and create another hybrid conflict area (Krastev 2015). Bosnian Serbs may also count on support coming from national quarters in Serbia. Finally, Bosnian Croats have the EU member Croatia on their side. Thus, the West faces high obstacles to overcome.

The self-interest of the West is also obvious and telling of their need to commit to the region. A "failed state" at the vulnerable south-eastern edge of the EU, with an over one thousand kilometre long border with EU member state Croatia, can bring many dangers. A border that is difficult to patrol efficiently leads to illegal migration, illegal trade of people and arms, as the legal situation of Bosnia-Herzegovina diverges greatly from European standards. Each issue signals horror for European politicians. Hence, it would be in the EU's best interest to increase the amount of invested resources and, at a minimum, the EU should maintain current levels of investment. If the West wishes to lead the country into 
the European Union and create a functioning state, a strategy between the "handson" and "hands-off" approach, clearly diverging from the Dayton construction, is needed. Linked to the EU's commitment to a European Bosnia are higher budgets to reform and stimulate the economy, making citizens more independent from political parties, and creating sustainable employment opportunities in the country. The vision could perhaps be regarded as a "European Marshall Plan for the Balkan region."

The West could, alternatively, resort to a policy used by the late Habsburg monarchy when faced with multiple challenges and crises: simply muddle-through perpetuating the limbo status of a situation. ${ }^{16}$ Not only would this practice degrade the Western model in the eyes of Bosnian citizens, but the continuation of a limbo state would encourage co-operation offerings from Turkey, the Gulf States, and Russia. The West does have the upper hand, however, as public opinion in Bosnia may err on the side of scepticism regarding offerings from the aforementioned external actors, preferring, instead, the terms of the British-German initiative and the Berlin Process.

\section{CONCLUSIONS FROM A VISEGRAD FOUR PERSPECTIVE}

Visegrad Four has proven to be engaged actors in Bosnia-Herzegovina through their diplomatic presence and project work fostered by bilateral communication. In their external communication, V4 often steps up as a group because the four countries together can avoid marginalisation in the competitive external realm. V4 also has the advantage of being perceived as an impartial actor, advocating strategies that are best for Bosnia-Herzegovina. This is the single most important advantage as compared to the regional V4 partner Croatia (as Croatia is perceived to advocate on behalf of the Bosnian Croat population in the country). The activities of V4 and two regional actors, Austria and Slovenia, are not coordinated. The Visegrad Group may benefit from strengthening links with the two by coordinating their positions and initiatives. All in all, the Visegrad Four are engaged in concrete project work that encourages Europeanization processes in the country. This engagement could even be boosted in the likely future. On the other side, the Visegrad Four keep a low profile with little involvement in the institutions of the international community. Unlike the Scandinavian countries and the Nether-

16 The original German term for "muddle-through" used by emperor Franz Joseph I was "durchwurschteln." 
lands, V4 is not willing to take over a more active role. ${ }^{17}$ This lack of involvement could be due to limited budgets and/or the conviction that V4 positions do not differ greatly from those of the more active European partners. Hence, despite their rhetoric for the importance of the Western Balkans, greater engagements in the form of greater financial commitments in Bosnia-Herzegovina do not appear beneficial for the Visegrad Four states.

\section{REFERENCES}

Bassuener, K. - Vogel, T. - Perry, V. - Weber, B. (2014): Retreat for Progress in BiH? - The German-British Initiative. Democratization Policy Council, Policy Paper November 2014, http://democratizationpolicy.org/pdf/briefs/DPC\%20Policy\%20Paper\%20-\%20Retreat\%20 for\%20Progress\%20in\%20BiH.pdf (accessed 15 December 2014).

Council of the European Union (2014): Foreign Affairs Council meeting, Council conclusions on Bosnia and Herzegovina (Luxembourg, 14 April 2014), http://www.consilium.europa.eu/ uedocs/cms_data/docs/pressdata/EN/foraff/142215.pdf, (accessed 15 July 2014).

Cviić, C. - Sanfey, P. (2010): In Search of the Balkan Recovery. The Political and Economic Reemergence of South-East Europe. London: Hurst and Company.

Despot, A. - Reljić, D. - Seufert, G. (2012): Zehn Jahre Einsamkeit. Stiftung Wissenschaft und Politik, SWP-Aktuell 23, http://www.swp-berlin.org/fileadmin/contents/products/aktuell/2012A23 despot_rlc_srt.pdf (accessed 3 March 2014).

Dzihic, V. (2009): Ethnopolitik in Bosnien-Herzegowina: Staat und Gesellschaft in der Krise. Baden-Baden: Nomos.

Euinside (2014): Who Can Restart Bosnia and Herzegovina?, http://www.euinside.eu/en/faces/eubosnia-european-integration-council-conclusions-april-14 (accessed 15 July 2014).

European Commission (2013): Bosnia and Herzegovina 2013 Progress Report, SWD (2013) 415 final. Brussels: European Commission.

European Commission (2014): Bosnia and Herzegovina 2014 Progress Report, SWD (2014) 305 final. Brussels: European Commission.

European Stability Initiative (2013): Lost in the Bosnian labyrinth. Why the Sejdic-Finci case should not block an EU application. ESI Discussion Paper, 7 October.

International Crisis Group (2014): Bosnia's Future. ICG Europe Report No. 232, 10 July.

Jakobson, P. V. (2009): Small States, Big Influence: The Overlooked Nordic Influence on the Civilian ESDP. Journal of Common Market Studies 47(1): 81-102.

Keil, S. (2013a): Multinational Federalism in Bosnia and Herzegovina. London: Ashgate.

Keil, S. (2013b): Europeanization, state-building and democratization in the Western Balkans. $\mathrm{Na}$ tionalities Papers: The Journal of Nationalism and Ethnicity 41(3): 343-353.

Keil, S. (2013c): Legal Misunderstandings, False Normative Hopes and the Ignorance of Political Reality. A Commentary on the recent ESI Report "Lost in the Bosnian Labyrinth." Democratization Policy Council, DPC Policy Note New Series 4.

17 Smaller states that form groups can exercise influence. A case study on Scandinavian countries is Jakobson (2009). A comparative perspective between Visegrad Four, Scandinavian countries, and the Benelux states is given in Walsch (2015). 
Keil, S. - Perry, V. (eds) (2015): State-Building and Democratization in Bosnia and Herzegovina. London: Ashgate.

Keranen, O. (2013): International statebuilding as contentious politics: the case of post conflict Bosnia and Herzegovina. Nationalities Papers: The Journal of Nationalism and Ethnicity 41(3): 354-370.

Král, D. - Bartovic, V. (2012): EU enlargement in 2012: Where do we stand? Europeum - Institute for European Policy, Working Paper.

Krastev, I. (2015): The Balkans are the soft underbelly of Europe. Financial Times, Opinion, 14 January 2015.

Moll, N. (2013): Fragmented memories in a fragmented country: memory competition and political identity-building in today's Bosnia and Herzegovina. Nationalities Papers: The Journal of Nationalism and Ethnicity 41(6): 910-935.

Risse, T. (ed) (2011): Governance without a state? Policies and politics in areas of limited statehood. New York and Chichester: Columbia University Press.

Strážay, T. (2012): Visegrad Four and the Western Balkans: A Group Perspective. The Polish Quarterly of International Affairs 4: 52-64.

Töglhofer, T. (2013): Vom Westlichen Balkan zum "restlichen Balkan"? Auswirkungen des kroatischen EU-Beitritts auf Südosteuropa. Deutsche Gesellschaft für Auswärtige Politik, DGAPAnalyse No. 8.

Tolksdorf, D. (2012): Die EU und Bosnien-Herzegowina. Außenpolitik auf der Suche nach Kohärenz. Baden-Baden: Nomos.

Visegrad Group (2012): Czech Republic - Report on the Czech Presidency of the Visegrad Group. July 2011 - June 2012, http://www.visegradgroup.eu/documents/annual-reports (accessed 10 April 2014).

Visegrad Group (2013a): Poland - Report of the Polish Presidency of the Visegrad Group. July 2012 - June 2013, http://www.visegradgroup.eu/documents/annual-reports (accessed 24 March 2014).

Visegrad Group (2013b): Joint Declaration of the Foreign Ministers of the Visegrad Countries and Croatia on the Occasion of the Croatian Accession to the EU, http://www.visegradgroup.eu/ calendar/2013/joint-declaration-of-the (accessed 15 July 2013).

Visegrad Group (2013c): Joint Statement of the Visegrad Group on the Western Balkans, http:// www.visegradgroup.eu/calendar/2013/joint-statement-of-the-131107 (accessed 26 June 2014).

Visegrad Group (2014a): Hungary - Hungarian Presidency of the Visegrad Group (2013-2014), http://www.visegradgroup.eu/documents/presidency-programs (accessed 4 September 2014).

Visegrad Group (2014b): Slovakia - 2014-2015 Slovak Presidency. Dynamic Visegrad for Europe and Beyond - Program of the Slovak Presidency in the Visegrad Group (July 2014-June 2015), http://www.visegradgroup.eu/documents/presidency-programs/20142015-slovak (accessed 4 December 2014).

Walsch, C. (2014): Fostering EU enlargement. Is the Visegrad Group a credible advocate? Andrássy Universität Budapest Donau-Institut Working Paper Series, No. 29.

Walsch, C. (2015): Historische Identitäten und regionale Zusammenarbeit in Zentraleuropa in vergleichender Perspektive. In: Walsch, C.: Aufbruch nach Europa. Sieben Beiträge zur europäischen Integration Ungarns seit 1990. Herne: Schäfer.

Żornaczuk, T. (2013): The Prospects of EU Enlargement to the Western Balkans in 2013. The Polish Institute of International Affairs, PISM Bulletin 24 (477) 


\section{Interviews with stakeholders}

1 Ambassador of Austria in Bosnia-Herzegovina, Sarajevo, 27 May 2014.

2 Embassy representative of Croatia in Bosnia-Herzegovina, Sarajevo, 29 May 2014.

3 High Representative of the International Community in Bosnia-Herzegovina, Sarajevo, 29 May 2014.

4 Ambassador of Poland in Bosnia-Herzegovina, Sarajevo, 30 May 2014.

5 Ambassador of Slovakia in Bosnia-Herzegovina, Sarajevo, 30 May 2014.

6 Embassy representative of the Czech Republic in Bosnia-Herzegovina, Sarajevo, 3 June 2014. 